\title{
The Use of Mineral Therapeutic Waters in Metabolic Disorders - a Review of the Literature
}

Adriana Sarah Nica', Gavril Lucian Gheorghievici', Brindusa Ilinca Mitoiu', Delia Clantau’', Gabriela Radulian?

\begin{abstract}
The ongoing concern regarding the management of the metabolic syndrome and its complications requires the permanent approach of therapeutic solutions. Balneotherapy has been used for much time for treatment of different illness. The most common uses of mineral therapeutic waters are represented by drinking or bath cures. The positive influence of this form of therapy can be attributed to the water composition and its physical chemical properties of the water firstly, and second to the climatic, nutritional and social factors that are specific to the balneary resort. The aim of the study was to express our current experience regarding the impact that balneary support has in managing different metabolic conditions. We performed a review using online databases, and also hand research of the available studies regarding the subject, in order to acquire more information regarding the research that was conducted on this field. The analysis indicates a significant amount of data regarding the use of mineral therapeutic waters, resulting that through their specific composition it can provide a modulation of the parameters that define the metabolic syndrome.
\end{abstract}

Keywords: mineral therapeutic waters, metabolic syndrome, diabetes mellitus

\section{Rezumat}

Sindromul metabolic și complicațiile acestuia necesită furnizarea continuă a unor soluții terapeutice. Terapia balneară este utilizată în diferite segmente de patologie atât în cura internă cât și externă. Influența pozitivă poate fi atribuită, pe de o parte compoziției apei, respectiv proprietăților fizice și chimice ale acesteia, iar pe de altă parte factorilor de natură climatică, nutrițională și socială specifice stațiunii balneare. Scopul studiului este acela de a exprima experiența actuală cu privire la efectul realizat de către apele minerale terapeutice în tratamentul diferitelor afecțiuni metabolice. Am realizat o analiză folosind bazele de date online privind studiile disponibile pe acest subiect, pentru a obține mai multe informații legate de cercetările efectuate în acest domeniu. Analiza indică un număr semnificativ de studii privind utilizarea apei minerale terapeutice, rezultând posibilitatea modulării anumitor parametrii responsabili pentru apariția sindromului metabolic în cazul utilizării acestei forme de tratament.

Cuvinte cheie: ape minerale terapeutice, sindrom metabolic, diabet zaharat

\footnotetext{
${ }^{\prime}$ "Carol Davila" University of Medicine and Pharmacy, Bucharest, Romania
}

\section{Corresponding author.}

Gavril Lucian Gheorghievici, „Carol Davila” University of Medicine and Pharmacy, Bucharest Romania.

E-mail: gavril.gheorghievici@gmail.com 


\section{BACKGROUND}

Metabolic Syndrome (MetS) represents a group of clinical and biological criteria that when combined can become a potential threat for the development of severe pathologies -diabetes mellitus, cardiovascular disease, obesity. The International Diabetes Federation (IDF) defines the presence of MetS when 3 or more of the following criteria are detected: 1. raised triglycerides $\geq 150 \mathrm{mg} / \mathrm{dL}(1.7 \mathrm{mmol} / \mathrm{L})$ or specific treatment for this lipid abnormality; 2. reduced HDL cholesterol $<40 \mathrm{mg} / \mathrm{dL}(1.03 \mathrm{mmol} / \mathrm{L})$ in males $<50 \mathrm{mg} / \mathrm{dL}(1.29$ $\mathrm{mmol} / \mathrm{L}$ ) in females or specific treatment for this lipid abnormality; 3. raised blood pressure systolic $\mathrm{BP} \geq 130$ or diastolic $\mathrm{BP} \geq 85 \mathrm{~mm} \mathrm{Hg}$ or treatment of previously diagnosed hypertension; 4. raised fasting plasma glucose, $(\mathrm{FPG}) \geq 100 \mathrm{mg} / \mathrm{dL}(5.6 \mathrm{mmol} / \mathrm{L})$, or previously diagnosed type 2 diabetes; 5 . central obesity (defined as waist circumference* with ethnicity specific values) (IDF guidelines) ${ }^{1-3}$.

The cause of MetS is not singular, central obesity and insulin resistance representing the core factors for its individual components ${ }^{4}$. Because of the epidemic of overweight and sedentary lifestyle worldwide, the metabolic syndrome is more frequently being diagnosed. The prevalence increases with age, especially during the six decade of life the estimated risk of further developing diabetes being 5 to 7 times higher in these patients compared to patients absent of the pathology ${ }^{5}$.

The presence of MetS not only increases the risk of developing diabetes but can be highly predictive regarding the new-onset of the disease. Also, increased cardiovascular and overall mortality, are associated with Mets even when in patients without diabetes or cardiovascular disease. The International Diabetes Federation (IDF) according to 2017 Diabetes Atlas expresses the fact the global prevalence of diabetes in the population aged $20-79$ years is $8.8 \%$ and is estimated to increase to $9.9 \%$ until $2045^{6}$.

The prevalence of metabolic pathologies according to PREDATORR study that evaluated the prevalence of diabetes mellitus and prediabetes, and their association with cardiometabolic, sociodemographic, and lifestyle risk factors in the Romanian population aged 20-79 years and included 2278 paticipants evidenced that impaired glucose regulation was found in $28.1 \%$ of the studied population, while the prevalence of diabetes mellitus was $11.6 \%$, increased with age and was higher in men than in women ${ }^{7}$.

Treatment options of metabolic syndrome include lifestyle changes, which requires the adoption of a healthy diet, increased physical activity, smoking cessa- tion plan and maintenance of a healthy body weight, physical exercise and pharmacological treatment of its different components if attempts to lifestyle changes are not adequate.

Balneotherapy has been used for much time for treatment of different illness. The most common uses of mineral therapeutic waters are represented by drinking or bath cures. The positive influence of this form of therapy can be attributed to the water composition and its physical chemical properties of the water firstly, and second to the climatic, nutritional and social factors that are specific to the balneary resort ${ }^{8}$.

\section{MATERIAL AND METHOD}

We performed a review using online available database - Cochraine, Pubmed/Medline (1966 - present), Pedro, Science direct Embase/ Elsevier (1980 - present) - and also hand research of the available studies regarding the subject, in order to acquire more data regarding the research that was conducted on this field. The following search terms were used: crenotherapy, mineral therapeutic waters, balneotherapy, metabolic syndrome, thermalism, obesity, diabetes.

\section{RESULTS AND DISCUSSIONS}

The search strategy evidenced encouraging results regarding the use of mineral therapeutic waters in this chapter of pathology.

The results of PRISMe, a French cohort study ${ }^{9}$ sustained by AFRETh which investigated the multidisciplinary care on the one year care of the metabolic syndrome during 2008-2009 followed the use of spa therapy combined with multidisciplinary management using NCEP-ATP III criteria and concluded that a quarter of the patients included in the study (from a total of 63/143 followed) presented a reduction of the criteria that were used to diagnose Mets.

Maathermes study ${ }^{10}$ (AFRETH, 2011) evaluated the efficacy of thermalism and its impact in patients with obesity. The study observed the effect of a 3 week cure in French balneoclimateric resorts, in which patients benefited from crenotherapy with mineral therapeutic waters, hydrokinetotherapy, mud wraps, and dietary counseling. The results show a comparable efficacy of a thermal cure compared to the single use of pharmacological treatment with agonists of $2 \mathrm{C}$ receptors of serotonine - Lorcacerin - and lifestyle modifications.

Drobnik $\mathrm{M}$ et al. express a reduction of total cholesterol and total lipids from the blood serum, in a study in which they analyzed the functioning biological activity of mean mineralized sodium bicarbonate in water 
from the „Pitoniakówka” source in Szczawnica outflow B + C + D + G.11, while Yamamoto N. (2007) provides additional information in which he states that immersion in $\mathrm{CO}_{2}$-rich water containing $\mathrm{NaCl}$ diminishes blood pressure fluctuation in anesthetized rats ${ }^{12}$.

Oláh $\mathrm{M}$ et.al studies the effect of balneotherapy on $\mathrm{C}$-reactive protein, serum cholesterol, triglycerides and total antioxidant status, on a group of 42 ambulatory patients that benefited from external cure with mineral therapeutic waters for 15 days, in which reduced values of triglycerides and cholesterol were observed at the end of the cure and maintained until the 3 month follow-up ${ }^{13}$.

The use of bicarbonate mineral therapeutic waters have been proven efficient in type 2 diabetes treatment. In study that used blood metabolome analysis in order to observe the effect of MTW on glycemic control, is was shown modifications on 19 metabolites including glycolysis related metabolites and 3 amino acids, and also a reduction of the glycoalbumin levels, suggesting that the administration of MTW could prevent or improve the status in patients with type 2 diabetes ${ }^{14}$.

Other studies express favorable results in managing patients with diabetes and obesity in case of using balneotherapy, with a diminish of body mass index and biological parameters including glycaemia, total cholesterol, and c reactive protein, the authors expressing that balneary programs associated with controlled diet could offer a risk reduction in metabolic patients ${ }^{15}$.

In a study that developed in the balneary resort which evaluated the development of selected cardiovascular parameters in patients with type II diabetes, the authors used different sources of mineral waters that include free $\mathrm{CO}_{2}$ dissolved in water in a dissociated form, both internally and also associated with other balneary forms of treatment and dietary interventions, the authors observed a reducing of the sympathoadrenal system activity in patients with poorly controlled diabetes type II, associated with an improvement of the electrical stability of the myocardium and heart rate variability without an overload of the cardiovascular treatment ${ }^{16}$.

Sulphurous mineral water have been shown to provide an effect over the oxidative stress in patients with diabetes, the author suggesting crenotherapy associated with antidiabetic medication, may be useful in type 2 diabetes mellitus for the improvement redox state of the organism ${ }^{17}$.

Other studies suggest a possible effect of balneotherapy on platelet glutathione metabolism in type II diabetic patients, the authors expressing the fact that balneotherapy can be beneficial for patients whose platelet antioxidative defense system is damaged, such as those with diabetes mellitus and coronary heart disease ${ }^{18}$.

The impact of hypersaline sodium-rich naturally mineral water with high concentration of potassium, calcium, and magnesium over the metabolic syndrome has been evaluated in a study on metabolic syndrome induction in fructose-fed sprague-dawley rats. The authors analyzed a large scale of metabolic parameters including plasma concentrations of glucose, triacylglycerols, total cholesterol, HDL-cholesterol, LDL-cholesterol, C-reactive protein (CRP), glutamicoxaloacetic transaminase (GOT), glutamic-pyruvic transaminase (GPT), total bilirubin, uric acid, urea, creatinine, total proteins, albumin, ferritin, sodium, potassium, chloride, magnesium, calcium, and phosphorus, observing that the ingestion of the mineral water reduced not only the fructose-induced increase of heart rate, plasma triacylglycerols, insulin and leptin levels, hepatic catalase activity, and organ weight to body weight ratios (for liver and both kidneys) but also the decrease of hepatic glutathione peroxidase activity and oxidized glutathione content implying that natural mineral waters could a have the potential to prevent metabolic syndrome induction by fructose ${ }^{19}$.

In a study regarding the effect of an intervention with sodium-bicarbonated mineral water on cardiometabolic risk biomarkers, the authors observed a reduction of total cholesterol, LDL cholesterol, and glucose, and a decrease in urinary potassium and creatinine concluding that mineral waters did not affect blood pressure and exerted a moderate alkalizing effect in the body ${ }^{20}$.

Sodium-bicarbonated mineral waters have been reported to reduces gallbladder emptying and postprandial lipaemia in a study which monitored postprandial serum triacylglycerols, cholecystokinin and gallbladder volume the authors observing a reduction of these parameters of the administration of bicarbonate mineral water ${ }^{21}$.

Other authors have analyze the effect of a strongly bicarbonated mineral water on lipoprotein levels during fasting and postprandial state, reporting a significant decrease in triglyceridemia and tendency to a decrease of VLDL cholesterol at fasting state ${ }^{22}$.

Crenotherapy may provide a modulation of the parameters that define obesity and diabetes, due to the fact that these conditions can occur as a result of the interference of gastric pathology, associated with hepato-biliary, and pancreatic manifestations. In a study that evaluated the effect of sulphate-bicarbonate-calcium water on risk factors for atherosclerosis, weight control, and gallstone disease over a 12 day cycle in patients with functional dyspepsia and constipation, 
in which the authors evaluated tota//low density lipoprotein and high density lipoprotein, bile acid, and the fasting gallbladder volume using the ellipsoid formula on the average of 2 sonographical gallbladder measurements, the authors observed an improvement intestinal transit and allows maintenance of a stable body weight despite a high food intake. Fasting gallbladder volume was significantly smaller at the end of the study than at baseline in the mineral water group $(15.7 \pm 1.1 \mathrm{~mL}$ vs $20.1 \pm 1.7 \mathrm{~mL}$ ) compared to tap water group (19.0 $\pm 1.4 \mathrm{~mL}$ vs $19.4 \pm 1.5 \mathrm{~mL}$ ). There were no significant difference regarding total cholesterol, HDL cholesterol, LDL cholesterol and triglycerides at the end of the cure compared to baseline ${ }^{23}$.

Additional, hand research was conducted in order to further evaluate the impact exercised on the metabolic functions by different categories of mineral waters. Stoicescu et al study the influence of Lipova bicarbonate calcic water on experimental models with alloxan induced diabetes. The authors observed a lower increase of the glycemic level (42\% increase in alloxan group compared with alloxan and mineral water which presented statistical significance) ${ }^{24}$.

Regarding the lipid metabolism, the mineral therapeutic water from Slanic Moldova, source 2 was studied, the authors expressing reduced levels of plasmatic fatty acids with $16 \%$ in the studied lot, while the cholesterol levels remains without and significant differences between the two groups). Similar results were found with Bilbor water source ${ }^{5}$. The authors also ex- plored the modifications of the serum lipid fractions in mice, and although the differences do not present significant values the author suggest an improvement of the reports of these fractions after the administrations of bicarbonate water ${ }^{25}$.

The role of the hydrogen sulfide from the composition of the sulphurous mineral waters may be reconsidered from the light of new researches. Yang et al provides evidence that $\mathrm{H} 2 \mathrm{~S}$ represents a physiologic vasodilatator and regulator of blood pressure ${ }^{26}$, while Zhang $\mathrm{L}$ et al. suggest that the interaction of $\mathrm{H} 2 \mathrm{~S}$ and insulin in liver plays a pivotal role in regulating insulin sensitivity and glucose metabolism ${ }^{27}$.

\section{CONCLUSIONS}

Mineral therapeutic waters though their specific physical and chemical composition can provide a modulation of the parameters that define the metabolic syndrome. Although our review indicates a significant amount of data on this subject, new research studies are required in order to observe the effect of mineral therapeutic waters in managing metabolic conditions.

Acknowledgement: This paper is supported by the Sectoral Operational Programme Human Resources Development (SOP HRD), financed from the European Social Fund and by the Romanian Government under the contract number POSDRU/187/1.5/S/156069.

\section{References}

1. Alberti KG, Zimmet P, Shaw J; IDF Epidemiology Task Force Consensus Group. The metabolic syndrome a new worldwide definition. Lancet 2005;366:1059-62.

2. Alberti KG, Zimmet $P$, Shaw J. Metabolic syndrome-a new world-wide definition. A Consensus Statement from the International Diabetes Federation. Diabet Med 2006 May;23(5):46980

3. DeFronzo RA, Ferrannini E 1991 Insulin resistance.A multifaceted syndrome responsible for NIDDM, obesity, hypertension, dyslipidemia, and atherosclerotic cardiovascular disease. Diabetes Care 14:173-194

4. Kahn BB, Flier JS 2000 Obesity and insulin resistance. J Clin Invest 106:473-481

5. Flegal KM, Carroll MD, Kuczmarski RJ, Johnson CL 1998 Overweight and obesity in the United States: prevalence and trends, 1960-1994. Int J Obes Relat Metab Disord 22:39-47 61. Mokdad AH, Bowman BA, Ford ES, Vinicor F, Marks JS, KoplanJP 2001 The continuing epidemics of obesity and diabetes in the United States. JAMA 286:1195-1200

6.. Q\&A: Key points for IDF Diabetes Atlas 2017 Diabetes Research and Clinical Practice, Volume 135, 235-236

7. Mota M, Popa SG, Mota E, Mitrea A, Catrinoiu D, Cheta DM et al. Prevalence of diabetes mellitus and prediabetes in the adult Romanian population: PREDATORR study. J Diabetes. 2016 May;8(3):336-44

8. Ilanne-Parikka P, Eriksson JG, Lindstrom J, Peltonen M, Aunola S, Hamalainen H, Keinanen-Kiukaanniemi S, Laakso M, Valle TT, Lahtela J, Uusitupa M, Tuomilehto J 2008 Effect of lifestyle intervention on the occurrence of metabolic syndrome and its components in the Finnish Diabetes Prevention Study. Diabetes Care 31:805-807

9. Bender T, Bálint G, Prohászka Z, Géher P, Tefner IK Evidence-based hydro- and balneotherapy in Hungary--a systematic review and meta-analysis. Int J Biometeorol. 2014 Apr;58(3):311-23

10. Gin H. Demeaux J.L., Grelaud A. Observation of the Long-term Effects of Lifestyle Intervention during Balneotherapy in Metabolic Syndrome Thérapie 2013 Mai-Juin; 68 (3): 163-167

11. Hanh T, Serog P, Fauconnier J, Batailler P, Mercier F, Roques CF, Blin P. One-year effectiveness of a 3-week balneotherapy program for the treatment of overweight or obesity. Evid Based Complement Alternat Med. 2012;2012:150839

12. Drobnik M, Latour T. Functioning biological activity of mean mineralized sodium bicarbonate in water from the "Pitoniakówka" source in Szczawnica, designed for health resort potable cures. Rocz Panstw Zakl Hig. 2001;52(1):41-7

13. Yamamoto N, Hashimoto M. Immersion in CO2-rich water containing $\mathrm{NaCl}$ diminishes blood pressure fluctuation in anesthetized rats. Int J Biometeorol. 2007 Dec;52(2):109-16. Epub 2007 Jun 15 
14. Oláh M, Koncz A, Fehér J et al. The effect of balneotherapy on C-reactive protein, serum cholesterol, triglyceride, total antioxidant status and HSP-60 levels. Int J Biometeorol. 2010 May;54(3):249-54

15. Murakami, Shinnosuke Goto Yasuaki Ito, Kyo et al. The Consumption of Bicarbonate-Rich Mineral Water Improves Glycemic Control. Evidence-Based Complementary and Alternative Medicine. 2015. 1-10. 10.1155/2015/824395

16. Fioravanti A, Adamczyk P, Pascarelli NA et al. Clinical and biochemical effects of a 3-week program of diet combined with spa therapy in obese and diabetic patients: a pilot open study. Int J Biometeorol. 2015 Jul;59(7):783-9

17. Sato M, Kanikowska D, Iwase S et al. Effects of immersion in water containing high concentrations of $\mathrm{CO} 2$ (CO2-water) at thermoneutral on thermoregulation and heart rate variability in humans. Int J Biometeorol. 2009 Jan;53(1):25-30. doi: 10.1007/ s00484-008-0188-x. Epub 2008 Oct 24

18. Costantino M, Giampaolo C, Filippelli A Effects of drinking spa therapy on oxidative stress Clin Ter. 2012;163(1):e13-7.

19. Ohtsuka Y, Yabunaka N, Watanabe I et al. Balneotherapy and platelet glutathione metabolism in type II diabetic patients. Int J Biometeorol. 1996 Sep;39(3):156-9.

20. Pereira CD, Severo M, Araújo JR, et al. Relevance of a Hypersaline Sodium-Rich Naturally Sparkling Mineral Water to the Protection against Metabolic Syndrome Induction in Fructose-Fed Sprague-Dawley Rats: A Biochemical, Metabolic, and Redox Approach. International Journal of Endocrinology. 2014; 2014:384583.
21. Toxqui L, Vaquero MP An Intervention with Mineral Water Decreases Cardiometabolic Risk Biomarkers. A Crossover, Randomised, Controlled Trial with Two Mineral Waters in Moderately Hypercholesterolaemic Adults. Nutrients. 2016 Jun 28;8(7)

22. Toxqui L, Pérez-Granados AM, Blanco-Rojo R, Vaquero MP. A sodium-bicarbonated mineral water reduces gallbladder emptying and postprandial lipaemia: a randomised four-way crossover study. Eur J Nutr. 2012 Aug;51 (5):607-14

23. Zair Y., Kasbi-Chadli F., Housez B., et al. Effect of a high bicarbonate mineral water on fasting and postprandial lipemia in moderately hypercholesterolemic subjects: a pilot study. Lipids in Health and Disease .2013;12:105.

24. Corradini SG, Ferri F, Mordenti M, et al. Beneficial effect of sulphate-bicarbonate-calcium water on gallstone risk and weight control. World Journal of Gastroenterology: WJG. 2012; 18(9):930-937

25. Stoicescu C. XIV Ses st INRMFB Bucuresti 1978

26. Stoicescu C, Barca Valeria, Hoanca V., Serban Gabriela (1972), Studii ce cercetare .balneologie, fizioterapie XI 368

27. Yang G, Wu L, Jiang B, Yang W, Qi J, Cao K, Meng Q, Mustafa AK, Mu W, Zhang S, Snyder SH, Wang R H2S as a physiologic vasorelaxant: hypertension in mice with deletion of cystathionine gamma-lyase 2008

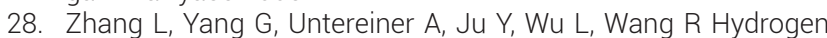
sulfide impairs glucose utilization and increases gluconeogenesis in hepatocytes 2013. 